\title{
Death Instinct and Creativity: With Works of Egon Schiele
}

\author{
Youn Jeong Choi ${ }^{1}$ and Jee Hyun $\mathrm{Ha}^{2}$ \\ ${ }^{1}$ Department of Psychiatry, Konkuk University Medical Center, Seoul, Korea \\ ${ }^{2}$ Department of Psychiatry, School of Medicine, Konkuk University, Seoul, Korea
}

\section{죽음충동과 창작심리: 에곤 실레의 작품을 중심으로}

\author{
최 윤 정 ${ }^{1}$ 하 지 현 ${ }^{2}$ \\ 건국대학교병원 정신건강의학과, ${ }^{1}$ 건국대학교 의학전문대학원 정신건강의학교실 ${ }^{2}$
}

\begin{abstract}
Death instinct was first introduced by Freud in 'Beyond the Pleasure Principle' in 1920. Dominant death instinct can negatively affect the balance of mental apparatus with a variety of psychopathologies. The author analyzed life and work of the Austrian painter Egon Schiele and tried to determine how death instinct affected his work. In this study, typical themes of his work were analyzed. The first theme analyzed was 'mother and child'. Typical mother-child attachment and emotional ties were not observed in his work. This reflected Schiele's detachment from his mother and a dominant death instinct in his mental apparatus. It also indicated a predominantly paranoid-schizoid position in object-relationship. The second theme was 'Self-portrait'. Usually the face in his self-portrait was grotesque and asymmetry. In some pieces, the genital was exaggerated or extremities were cut. These selfportraits reflected Egon Schiele's ego. He was asexual. He indulged in masturbation due to phobia of syphilis which took his father's life and mental. These works showed that he was preoccupied by death instinct which also caused psychological developmental arrest in various aspects. With the work of 'Death and the Maiden' in 1915, he accomplished maturation of sexuality with integration of death instinct and libidinal instinct. By creative working for several years, he could overcome his unconscious predominant death instinct and 'paranoid-schizoid position'. In conclusion, death instinct could distort normal mental functioning, it also could be mastered by creative activity.

Psychoanalysis 2017;28(3):58-68
\end{abstract}

KEY WORDS: Death instinct · Creativity $\cdot$ Egon Schiele.

Received: May 29, 2017 Revised: June 22, 2017 Accepted: June 22, 2017

Address for correspondence: Jee Hyun Ha, MD, PhD

Department of Psychiatry, School of Medicine, Konkuk Univeristy, 120-1 Neungdong-ro, Gwangjin-gu, Seoul 05030, Korea

Tel: +82-2-2030-7569, Fax: +82-2-2030-7748, E-mail: jhnha@naver.com

서 론

죽음 충동(death instinct or drive, 독: todestrieb)은 '모든 생물이 무생물의 상태로 돌아가고자 하는 근본적 경향’을 뜻 하며 프로이트가 ‘Beyond the Pleasure Principle’(Freud 1920) 에서 처음 도입했다. 프로이트는 초기에 성적 리비도 충동과 자아 충동을 개별적인 것으로 보았으나 자기애의 개념을 도 입하면서 이러한 구분을 없애고 리비도의 서로 다른 모습으 로 평가했다. 그러나 성적 리비도 충동과 자아 충동을 포함 하는 광의의 리비도와 이 리비도의 일원론만으로는 증오나 가학증과 같은 다양한 설명을 하기에는 무리가 있었다. 이에

This is an Open Access article distributed under the terms of the Creative Commons Attribution Non-Commercial License (http://creativecommons.org/licenses/by-nc/4.0) which permits unrestricted non-commercial use, distribution, and reproduction in any medium, provided the original work is properly cited.
프로이트는 이전의 쾌락 원칙만으로는 설명할 수 없었던 생 명체를 죽음으로 이끌려고 하는 충동의 존재가 생명의 시초 에서부터 존재한다는 점을 지적하면서 타나토스(thanatos) 라는 죽음 충동의 개념을 도입하였다(Freud 1920). 그는 삶 의 충동과 죽음 충동의 대극적인(oppositional) 두 축을 갖는 새로운 정신 기구 모델을 구상하여 이원론적 개념으로 이중 욕동 이론(dual drive theory)으로 명명하였고, 이후 메타심리 학적인 개념으로 통합시켰다(Freud 1923). 삶의 충동(life instinct, eros)은 성적인 본능, 일차 및 이차 자기애, 대상 리비 도의 개념을 포함하고, 죽음 충동(death instinct, thanatos)은 파괴 본능, 일차적 파괴성, 대상과 자기를 향한 공격성의 요 소들을 포함한다. 프로이트는 삶을 죽음 충동과 삶의 충동 사이의 갈등과 타협의 과정으로 보았으며 정신기제는 이 두 요소가 다양한 비율로 광범위하게 융합되거나 합병된 혼합물 이라고 하였다(Freud 1923). 그는 목적의 관점에서 공격 욕동 
혹은 파괴 욕동이라고 명명할 수 있는 존재가 있으며, 이는 생 물의 타고난 죽음 충동에서 유래한 것으로 보았다. 에로스의 목적이 더 큰 단위를 형성하고 유지하고자 하는 결합의 방향 성을 지닌다면, 타나토스의 목적은 이와는 반대로 집합을 해 체하고 사물을 파괴하려는 방향성을 지닌다.

정신적인 발달 단계에서 죽음 충동은 자아의 조절 대상이 된다. 자아는 발달 단계를 거치면서 현실 검증력, 충동 및 정 동의 조절과 통제, 대상 관계의 형성, 사고, 적응적 퇴행, 방 어, 자극 차단 등의 다양한 기능을 수행한다(Bellak와 Meyers 1975). 자아는 이드의 맹목적 충동을 적절히 지연시키거나 우회시킴으로써 합리적인 방식으로 욕구를 충족할 수 있게 한다(Freud 1923). 그러나 죽음 충동의 요소가 삶의 충동의 요소보다 우세하거나 충동을 적절히 통제할 수 있을 만큼의 건강한 자아로 자아가 발달하지 못한 경우, 자아 및 초자아 는 전체적 통합에 실패한다(Kernberg 1976). 이처럼 통합에 실패한 자아는 기능을 상실하고 스스로 병적인 리비도의 대 상이 되거나 파멸의 대상이 될 수 있다(Freud 1923).

멜라니 클라인과 대상 관계 이론 학파는 프로이트의 이중 욕동 이론을 계승하여 인간의 근원적 불안을 죽음 충동에서 찾고자 하였다(Klein 1975). 그들은 죽음 충동과 삶의 충동 으로 이루어진 프로이트의 이원론을 다시 확인하였으며 태 생부터 죽음 충동이 개인에게 중요한 역할을 한다고 주장하 였다. 또 Winnicott(1971)이나 Kernberg(1975)와 같은 학자 들도 죽음 충동이 선천적이며 인생 초기의 상호작용 형성에 있어서 중요한 역할을 한다고 보았다.

죽음 충동은 정신분석 이론에서 초기에 상당히 중요한 개 념으로 다루어졌으며 이후 대상관계 이론을 통해 계승되었 으나 주류 정신분석학에서는 주목되지 않았다. 따라서 Laplanche와 Pontalis(1967)는 죽음 충동을 '가장 논란이 되 는 개념 중 하나'라고 하기도 하였다. 하지만 죽음 충동은 다 시 한 번 조망을 받을 필요가 있다고 생각한다. 특히 죽음 충 동이 우세한 정신세계를 가진 사람의 정신병리와 삶의 적응 문제, 그리고 이를 극복하여 균형을 이루어 가는 과정은 임상 적으로도 드물지 않게 접하는 부분이다.

존재하는 것을 파괴하려고 하거나 무(無) 혹은 생명이 없 는 상태로 돌아가고자 하는 죽음 충동이 한 개인의 정신 기제 에서 상당히 우세한 위치를 점령하고 있을 때 이를 자아가 온 전히 통제하기 어렵다. 정신분석과 예술적인 창조 활동은 손 상된 자아의 통합기능을 강화시켜 분열된 자아를 극복하게 하며(Freud 1940a; Freud 1940b) 자아의 현실 검증력을 높여 주고 내부와 외부 현실을 성공적으로 완숙(mastery)하는 능력 을 강화시키는 공통점을 지닌다(Rose 1987). 자아 심리학의 관점에서 볼 때 작품의 창작은 일종의 적응적 행동이며 $(\mathrm{Nie}-$ derland 1976), 창작을 통해 자아는 내부 및 외부 현실로부터 의 요구를 적절하게 통합시키고 자신과 현실에 대한 통찰력 을 높이며 새로운 방식으로 삶에 대처할 수 있게 된다(Noy 1978). 따라서 예술가는 창작 행위를 통해 자신의 자아를 성장 시키고 내재적 충동을 성공적으로 완숙(mastery)할 수 있다.

죽음 충동은 자아의 통제를 벗어날 때 매우 강렬한 자기 파괴적인 특성을 갖게 된다. 저자들은 죽음 충동이 개인의 무의식과 의식에 지배적인 영향을 미칠 때 창작 심리에 기 반을 둔 예술 활동이 죽음 충동을 조절할 수 있게 하는지와 예술 활동을 통한 죽음 충동의 조절이 어떠한 결과를 초래 할 것인지에 대한 의문을 갖게 되었다.

에곤 실레(Egon Schiele, 1890 1918)는 오스트리아의 대 표적인 표현주의 화가로 예술적 주제와 형식에 있어 급진적 이고 독자적인 스타일을 정립했다. 그는 탁월한 드로잉을 바 탕으로 독특한 색채를 사용하여 관객에게 강렬한 심리 반응 을 일으켰다. 작품의 형식뿐만 아니라 주제면에서도 다른 예 술가와 차별화되는 독창성을 갖고 있었는데 자신의 정신 세 계와 자아에 몰두하였기 때문에 작품에 내포된 자전적인 요 소가 많았다. 그는 반복해서 죽음을 주제로 한 작품을 생산 해냈고, 표현주의적 기법을 기반으로 한 독창적이고 기괴한 표현으로 평단과 대중의 관심을 받았다(Whitford 1981). 저 자들은 에곤 실레가 왜 이토록 죽음과 관련한 내용에 집착을 하였는지, 그리고 그의 중기와 후기의 작품에서 나타난 변화 가 죽음 충동과 어떠한 연관 관계를 갖고 있는지에 대해 정 신 분석적 측면에서 고찰해 보고자 한다. 이에 저자들은 본 논문에서 에곤 실레의 생애를 개괄한 뒤, 초기와 후기 예술 작품의 변화를 정신 역동적 방법으로 비교함으로써 그의 예 술적 창작 과정이 자아의 성숙에 어떠한 영향을 주었는지 밝혀보고자 한다.

\section{본 론}

\section{에곤 실레의 생애(1890 1918)}

에곤 실레는 1890년 6월 12일, 빈에서 서북쪽으로 $30 \mathrm{~km}$ 떨어진 작은 도시 툴른에서 아버지 아돌프 실레와 어머니 마리 실레 사이에서 출생했으며, 1 남 3녀 중 셋째로 두 누나 와 여동생이 있었다. 그는 제국 철도의 고급 관료였던 아버 지를 둔 중산층 집안의 자녀였으나 어린 시절 아버지가 신경 매독으로 발작을 하여 직장을 잃게 된 후 불안정한 삶을 살게 되었다. 에곤 실레는 툴른에서 초등학교를 졸업한 뒤 1901년 크렘스에 위치한 친척집에 머물며 김나지움으로 진학하였으 나 규격화된 생활을 강요하는 학교에 적응하지 못하여 1학 년 과정을 통과하지 못하고 유급되었다. 집으로 돌아온 후 
1902년 클로스터 노이부르크 수도원에서 운영하는 분데스 레알 김나지움으로 재입학하며 가족들과 함께 이사했다. 1905년, 실레의 아버지는 신경매독의 정신증상으로 연금이 보장된 철도 채권과 주식을 모두 불태워 버리고 사망하였고 이후 가족들은 모든 재산을 잃게 되었다. 실레는 이후 친척 들의 후원으로 학업과 생활을 하였다. 그는 김나지움의 신 부, 미술교사 등에게 미술적 재능을 인정받기도 하였으나 성 적은 하위권이었다. 1906년, 가족들은 그가 철도공무원이 되 기를 바랐지만 에곤 실레 본인은 화가가 될 결심을 하였고, 빈 미술 아카데미에 지원하여 합격했다. 입학 후 2년 동안 교 수들에게 좋은 평가를 받았고, 17세경인 1907년 클림트를 만 나기 시작하여, 오랫동안 클림트에게 영향을 받으며 여러 면 에서 실질적인 도움을 받는다. 클림트의 도움으로 후견인을 소개받았고 1908년부터 빈 미술공방에서 일하기도 하였으며 첫 전시회를 열었다. 1909년 4월, 빈 미술 아카데미의 미술에 대한 낡은 사고방식에 반감을 가진 에곤 실레는 몇몇 학생들 과 함께 개혁 요구 안을 제시했으나, 이를 학교가 받아들이지 않고 퇴학을 시키기로 하자 동료들과 자퇴를 하고 신예술가 그룹을 만들었다. 이후 실레는 독자적 작품 활동을 하면서 클 림트의 추천으로 신예 예술가로서 국제적인 주목을 받기 시 작했다. 1910년, 20세가 된 실레는 클림트와 빈 분리파의 양 식에서 탈피하여 자신만의 독자적인 스타일을 구축한다. 1911년, 그는 클림트로부터 발리라는 여성 모델을 소개받고 애인으로 발전하여 4년간 동거하였다. 한편 실레는 어린 소 녀들이 등장하는 성적인 주제를 담아낸 드로잉을 그렸다가 1912년 4월 경찰에 연행되어 3주간 구금되고 재판을 받기도 했다. 1913년, 실레는 클림트가 회장으로 있던 '오스트리아 예술가 연합의 회원이 되었고 빈에서 열린 국제 흑백전시회 와 분리파 전시회에 작품을 출품하며 화가로서 두각을 나타 냈다. 1915년, 동거녀였던 발리와 헤어지고 퇴임 공무원의 딸인 에디트 하름스와 결혼을 하였다. 결혼 후 나흘 만에 1차 세계전쟁에 징집되었지만 실레는 당시 이미 유명 화가의 반 열에 오른 상태였기 때문에 군인신분으로도 창작활동을 지 속할 수 있었다. 1918년, 클림트가 사망하자 에곤 실레는 빈 에서 가장 선두에 선 화가로 인정받았고 클림트와 견주는 작 가로 찬사를 받으며 오스트리아 화단의 중심이 되었다. 그러 나 1918년 당시 창궐하던 스페인 독감으로 임신한지 6개월 이 된 아내 에디트가 사망하였고, 실레 또한 스페인 독감에 전염되면서 3일 후인 1918년 10월 31일, 28세에 사망하였다.

\section{어머니와 죽음}

에곤 실레는 어머니를 소재로 하여 죽음의 주제를 표현한 그림을 여러 점 그렸다. 이 그림들은 1910년부터 1914년 사이
에 주로 제작되었다. 1910년의 '죽은 어머니 I(Dead Mother I)' (Figure 1)는 강보에 싸인 아기를 안고 있는 어머니의 모습 을 묘사했다. 검은 배경과 비슷한 어두운 색감의 강보는 어 머니의 형체와 하나가 되어 아기를 둘러싸고 있다. 어머니의 얼굴과 손은 시체처럼 마르고 혈색이 없는데 아기의 붉은 혈 색과 대비를 이룬다. 1913년의 '성가족(The Holy Family)'은 일반적 종교 성화를 기반으로 이를 재해석한 그림이다. 각각 요셉, 마리아, 예수를 상징하는 아버지, 어머니, 아기를 다른 형태의 구도로 그렸다. 아버지는 에곤 실레, 어머니는 발리의 얼굴로 추정된다. 아기는 강보에 싸여 있는데 마치 자궁 내에 있는 것처럼 묘사되었으며, 그 안에서 갇혀 불안해 하며 갇힌 상태에서 벗어나고 싶어 하는 것으로 보인다. 혹은 태어나지 못한 채 자궁 안에 남은 것으로도 보인다. 어머니의 시선은 아 기가 아닌 다른 곳을 보고 있는데 아기와 교감이 없고 냉담해 보인다. 어머니의 왼쪽 손은 다가오는 아버지를 밀어내고 있 으며 아버지는 그림의 구도 밖으로 밀려나 있고 무력해 보인 다. 성가족을 구성하는 세 명의 가족의 시선은 모두 각기 다른 곳을 응시하고 있다. 1914년의 '눈먼 어머니(Blind Mother)' (Figure 2)에서는 음울한 배경에 아기를 안고 있는 어머니가 그려져 있다. 어머니와 아기 모두 눈이 그려져 있지 않고 서 로의 얼굴 방향은 상대방을 향하지 않는다. 아기는 어머니의 가슴을 향해 있으며 젖을 먹으려고 하지만 매우 불편해 보인 다. 전라인 어머니의 손과 발은 배경에 의해 가려져 잘려진

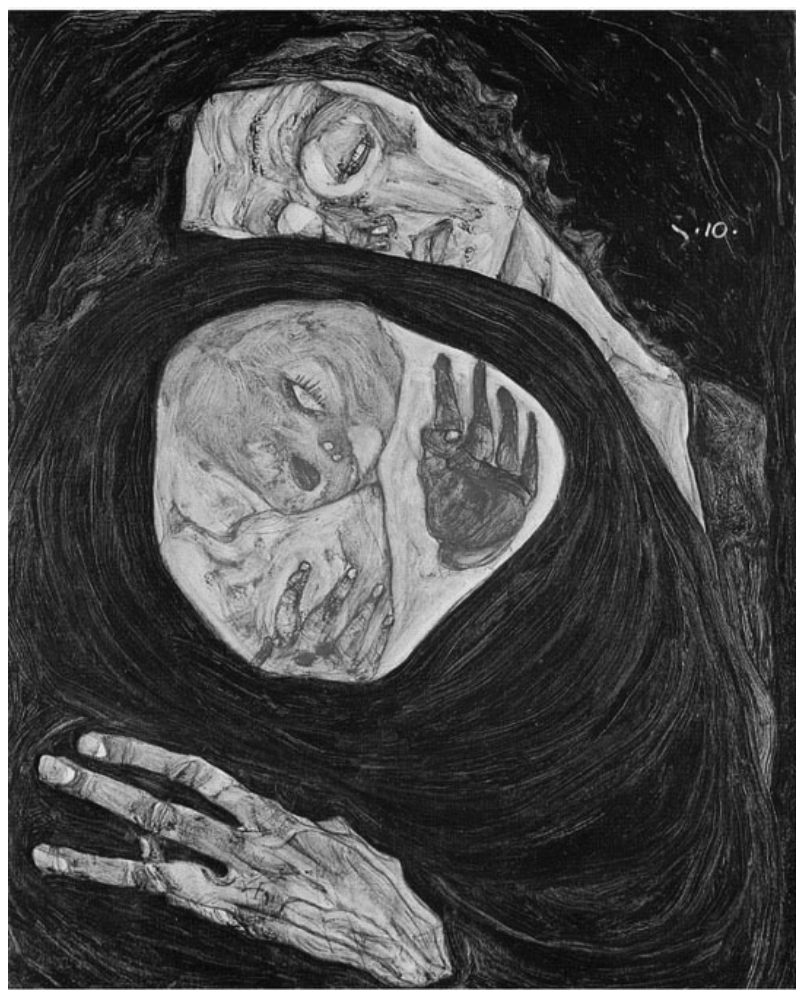

Figure 1. Dead Mother I (1910). 


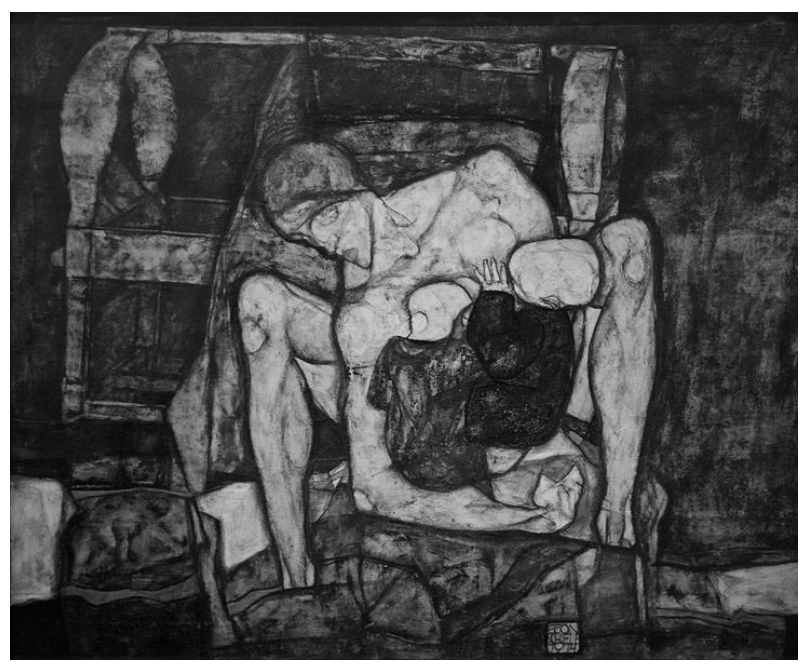

Figure 2. Blind Mother (1914).

것으로 보인다. 어머니는 머리카락이 없고 마른 피부에 굳은 표정을 하고 있어 생명이 없는 조각상처럼 보인다.

이처럼 에곤 실레는 작품을 통해 어머니와 아이의 관계를 묘사하면서 죽음을 연상시키거나, 모자 사이의 애착과 정서 적인 교감이 부재한 모습으로 표현했는데 이는 실제 그의 삶 과 밀접한 연관이 있다.

어머니 마리 실레는 16 세에 28 세의 아돌프 실레와 결혼하 였다. 이때 아돌프 실레는 매독에 감염된 상태였기에 마리 실레도 남편에 의해 매독에 전염되었고 수직감염으로 세 아 이를 사산하였다. 에곤 실레가 4 세가 되었을 때 10 세이던 큰 누나가 선천 매독 감염의 합병증으로 사망하였다. 이처럼 에 곤 실레의 어머니는 반복적으로 자녀의 사망을 경험하였고, 에곤 실레는 자식의 죽음을 경험한 어머니를 직접적으로 목 격했을 가능성이 있다. 또한 신경 매독으로 인한 남편의 기이 한 행동과 급작스러운 실직, 경제적인 어려움, 여러 차례의 사산 및 반복되는 임신에서 느껴지는 사산과 감염에 대한 불 안은 마리 실레의 정동을 지배했을 것이다. 이 같은 삶을 살 아온 실레의 어머니는 에곤 실레의 유아기에 필요한 적절한 돌봄 활동이나 애착을 위한 정서적 교감을 제공하지 못했을 것이다. 또 에곤 실레의 어머니는 아이의 정서적 요구에 적 절한 반응을 보여주지 못했을 것이다. 어머니의 반복적 사산 과 형제의 죽음, 그리고 매독에 감염된 부모가 일상적으로 경험하는 죽음에 대한 두려움 등을 통해 실레가 어린 시절에 경험한 가정의 분위기가 어둡고 죽음과 가까이 있었을 것으 로 추정할 수 있다. 더욱이 수년간 이와 같은 심리상태가 지 속되었기에 에곤 실레의 어머니는 실레의 미술적 재능에 대 해 관심을 가질 수 없었을 것이다. 실레는 어린 시절부터 드 로잉에 뛰어난 소질을 보였으나 그의 어머니는 아들의 재능 을 후원하고 지지하기보다는 그의 예술적 재능을 평가절하
하거나, 그림에 대한 열정을 받아들이지 않았다. 실레의 어 머니는 실레가 16 세가 되어서야 미술학교 진학을 지지하고 후견인이었던 숙부 치하체크가 실레의 후원을 지속할 수 있 게 설득하였다. 그런 연유로 이후에 에곤 실레는 미술 비평 가 아르투르 뢰슬러에게 다음과 같이 말했다.

"내 어머니는 참으로 이상한 분이셨습니다. 어머니는 나 를 조금도 이해하려 애쓰지 않았고 사랑하지도 않았어요. 어 머니가 사랑과 이해심을 지녔다면 나에게 좀 더 희생적이셨 을 테지요."(Whitford 1981)

실제 에곤 실레는 자신의 결혼식에 어머니를 초대하지 않 았고 자신이 죽기 직전에도 어머니가 아닌 장모에게 자신의 간병을 맡겼다.

이와 같이 이런 두 사람의 관계를 보면, '어머니'와 ‘죽음'의 주제가 그의 작품에서는 왜 이토록 밀접한 관계를 보이는지 이해할 수 있다. 일반적으로 어머니는 생산, 리비도, 평온함, 보살핌과 관련되어 있으며 어머니라는 존재를 통해 구원을 얻거나, 안식을 취하게 된다. 또 대부분의 예술 작품에서 나 타난 어머니의 이미지도 그러하다. 그러나 에곤 실레의 작품 에서 어머니는 오히려 죽음의 연장선상으로 묘사된다. 이처 럼 실레는 죽음과 밀접하고 파괴적인 분위기가 지배적인 가 정환경에서 성장하였으며, 주양육자이던 실레의 어머니는 음 울하고 불안정한 정동을 지니고 있었다. 이로 인해 실레는 생 애 초기의 애착 형성과 안정적인 대상관계의 형성에 어려움 을 겪었을 것으로 생각한다.

자아의 발달과정에서 어머니와의 대상관계는 매우 중요 한 요소 중 하나이다. 초기 자아는 자기 표상과 대상 표상을 분리해 낸 뒤 리비도적 충동 파생물의 영향하에 형성된 자 기 표상과 대상 표상이 공격적 충동 파생물의 영향으로 오 염되는 것을 막기 위해 적극적으로 분열(splitting)의 방어 기 제를 사용한다. 이후 정상 발달과정을 겪으며 원시적인 방어 기제의 사용은 서서히 감소하고 공격성이 투자된 심리 내적 구조를 리비도가 투자된 심리 내적 구조와 하나로 통합해 내는 것이 일반적이다(Kernberg 1976). 이러한 발달 과정은 주양육자를 통한 안전한 수준의 허용과 제한적인 좌절을 적 절히 경험하는 것으로 얻을 수 있다. 그렇게 성장한 아이는 공생 관계의 분리로 인한 어려움들에 건강하게 대처해 나가 며 통합된 자기 표상 및 대상 표상을 갖게 된다(Mahler 등 1975). 이 시기에 에곤 실레는 어머니로부터 좋은 어머니상을 내재화하면서 안정적인 대상 항상성을 형성할 기회를 갖지 못하였다. 그 결과 실레는 자기 표상과 대상 표상의 통합을 이 루지 못하여 안정되고 적절한 자아 정체성 및 대상 항상성의 성취에 실패했을 수 있다. 불우한 가정 환경과 우울한 어머니 는 실레의 무의식적인 구조에서 '나쁜 어머니(bad mother)'의 
대상 표상이 보다 우세하게 하였다. 취약한 좋은 어머니 표상 이 강력한 나쁜 어머니 표상에 의해 파괴될 수 있다는 위기감 은 실레가 초기 대상관계에서 편집-분열 자리(paranoidschizoid position)를 보다 주도적으로 발달하게끔 하였다. 이 같은 과정을 통해 성장한 실레는 성인이 된 이후에도 죽음충 동이 우세한 상태가 평형을 이룬 채 발달하였을 것이다. 생 애 초기의 적절한 대상관계 형성의 실패는 오이디푸스 이전 시기(pre-oedipal period)의 부정적인 특성을 유발하고 오이 디푸스 체계를 왜곡하여 성격 형성에 손상을 남겨 놓을 수 있 다(Blum 1977). 또한 큰 누이의 사망과 여동생의 출생은 에곤 실레가 성장기에 오이디푸스적 애착을 형성(oedipal attachment)하는 데 있어 중대한 저해요인이 되었다. Kernberg(1980) 는 이러한 실패가 전오이디푸스적(pre-oedipal)인 어머니 상 에 대한 방어적인 평가 절하와 두려움을 유발하고 오이디푸 스적 어머니에 대하여 적대감을 갖게 하는 특징적인 왜곡을 초래한다고 하였다. 따라서 자아는 어머니에 대한 방어적인 혹은 투사된 적개심을 보이는 동시에 자신이 어머니에게 갖 는 적개심에 대하여 병적인 죄책감도 갖게 된다(Kernberg 1976; Kernberg 1980).

이를 바탕으로, 에곤 실레가 어머니를 주제로 하는 초기 작 품에서 자신의 어머니를 '이미 죽은 존재'로 표현한 것은 오이 디푸스적 맥락 안에서 어머니에 대한 성적인 긴장이 유발하 는 공포에서 회피하려는 무의식적 시도였다. 또 어머니의 존 재를 근원적으로 부정함으로써 모성 박탈이 주는 절망에서 스스로를 방어하고자 하는 일종의 '역공포반응(counterphobic reaction)'이나 '반동 형성(reaction formation)'의 일종을 반복 강박적으로 그림으로 표현하였던 것으로 해석할 수 있 다. 더 나아가서 자신을 유기(abandonment)한 어머니에게 발산된 강렬한 공격성이 살해 충동으로 전환되는 것을 예술 적 표현으로 승화시킨 것이었다.

예술은 주관적인 표현으로 정신적인 현실(psychic reality) 을 다루는데, '죽은 어머니 I', '천재의 탄생(죽은 어머니 II)', '성가족' 등 자신과 어머니의 관계를 주제로 하는 작품에서 자궁과 비슷한 강보가 반복적으로 등장한다. 이는 태어난 뒤 에도 어머니에게 살아있는 것으로 인정받지 못했던 과거의 유기(abandonment)경험에 대한 표현이거나 출생 후에도 온 전한 자기감을 형성하지 못하고 혼돈 속에서 살아가고 있는 자신의 자아에 대한 예술적 묘사다. 이를 애착 이론적 측면에 서 보면 에곤 실레는 어머니와의 관계에서 절망(despair) 상 태에 머무른 경험이 많았던 것을 반영한다. 동시에 강보 안에 들어가 안전한 상태로 있고 싶은 염원을 역설적으로 표현하 고 있는 것이다. 인간은 손상된 내적 대상을 복구하려는 복구 충동(reparative drives)을 갖는데 손상된 대상에 대한 복구는
자아와 대상 관계 발달에 있어 기초가 되며, 공격/죽음 충동 을 승화하는 데 있어 결정적인 역할을 한다(Segal 1981). 또한 창조성(creativity)은 복구 충동과 깊은 관련을 갖고 있는데 에곤 실레가 어머니를 주제로 하는 작품을 반복적으로 다룬 것은 어머니와의 대상 관계 실패에 대한 복구 충동의 일환이 었다고도 해석할 수 있다.

\section{자화상}

에곤 실레는 자화상을 다른 화가들에 비교해 많은 양으로 약 300점을 완성했다. 일반적으로 자화상은 내면의 이미지 를 투사한 것이라 할 수 있는데 그의 자화상은 독특하게 얼 굴과 몸을 왜곡해서 묘사하고 있다. 초기에 그린 몇 편의 자 화상을 보면 다음과 같다. 1910년의 '벌거벗은 자화상(Nude, Self-portrait)'(Figure 3)에는 뒤틀린 얼굴로 자신을 묘사하 고 있다. 안면은 불균형을 이루고 있고 표정은 오르가즘에 도달한 듯이 이완되어 있다. 성기는 뭉개져 있으며 몸은 여 성의 것에 더 가까울 정도로 마르고 유방이 발달되어 있는 듯 하다. 또 양쪽 팔과 다리가 잘려져 있다. 1911년 작 ‘에로스'는 의자에 앉아 자위행위를 하고 있는 자화상이다. 발기한 페니

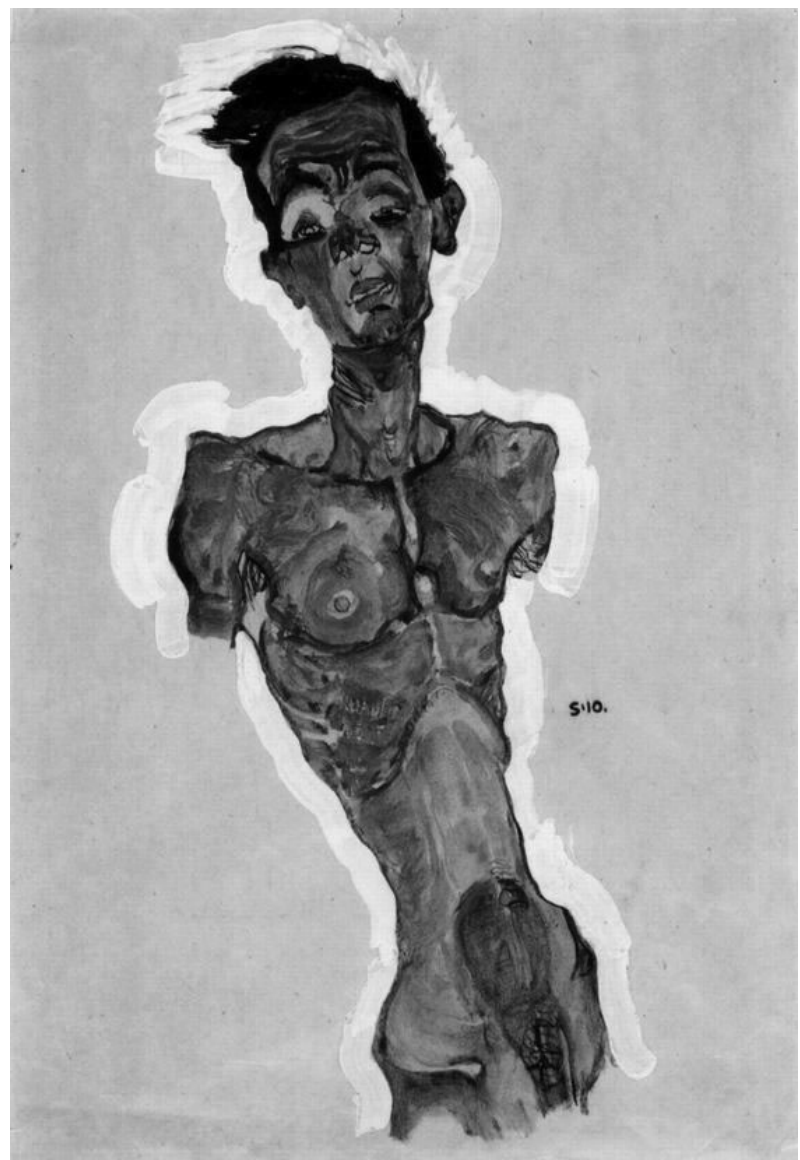

Figure 3. Nude, Self-portrait (1910) 
스는 신체에 비해 크게 그려져 있고 선명하게 강조되었다. 얼 굴은 불만에 가득 찬 듯 정면을 노려보고 있다. 1911년의 '인 물 구성-삼중 자화상'은 자화상으로 제목을 붙였으나 세 명 의 남자가 다양한 포즈로 등장한다. 붉은 색채로 인물들 간의 경계가 불분명하다. 가장 아랫부분에 위치한 남성은 생각에 잠긴 듯 고개를 숙이고 있으며 오른쪽 눈은 뜨고 있으나 왼 쪽 눈은 감겨 있고 전체적인 얼굴은 뒤틀려 있다. 중앙의 남 자는 오른쪽으로 고개를 기울인 채 앉아 정면을 바라보고 있다. 가장 상단에 위치한 남성은 오른쪽 팔을 머리에 들어 올린 채 머리를 오른쪽으로 꺾고 정면을 바라보고 있다.

실레는 자화상을 1910년과 1912년 사이에 집중적으로 그렸 는데 이 시기는 빈 아카데미를 그만두고 스스로 화가로서의 정체성을 만들어 가기 위해 노력하던 때이다. 이 시기에 그려 진 방대한 양의 자화상은 이 같은 실레의 심리과정이 적극적 으로 반영된 것으로 그의 내면이 예술에 투영된 결과이다. 자 화상 속의 실레는 손발이 잘리고, 과도한 성적 욕망에 사로잡 혀 있지만 행복하거나 즐겁지 않고, 한 사람으로 통합되지 못 하고 세 가지 표상이 혼재되어 있는 상태다. 이와 같이 왜곡 된 자화상들은 실레가 안정된 자아상과 자아의 기능을 갖지 못한 상태였던 것을 추정하게끔 해주는 증거이다.

에곤 실레는 건강한 정체성 형성에 실패하면서 자신의 좋 고 나쁜 측면들(그리고 그들 각각의 표상들)을 통합하지 못 했고, 정체성 혼돈이 오며(Erikson 1956; Kernberg 1976), 충 동 조절, 불안에 대한 내성, 승화할 수 있는 잠재력이 발달하 지 못하게 된다(Kernberg 1976). 그는 이중 및 삼중 자화상 을 통해 자신의 분열된 자아를 작품에 직접적으로 표현함으 로써 자아의 내적 통합의 실패를 보여주었다. 질서, 대칭, 조 화, 균형의 요소를 포함하여 예술에서 '완벽한 형태'를 찾으 려고 하는 것은 자아가 조직화하려는 노력의 일부이며, 자아 의 활동을 반영한다(Noy 1979). 그런데 실레는 자신의 몸과 얼굴을 왜곡시켜 부조화와 불균형을 극명하게 보여줬다. 이 와 같은 자화상은 그가 무의식적으로 자신의 몸도 정상적인 균형과 발달적 완성을 이루지 못한 상태로 인식하고 있는 혼 돈의 상태라는 것을 반영하고 있다. 그는 스스로 자기 신체 이미지에 결함이 있고, 리비도를 외부의 대상을 향해 건강하 게 표현하지 못한 채 자위에 몰두하며 현실이 아닌 성적 환상 에 사로잡혀 있는 상태로 인정하고 있다. 이는 당시 그가 발 리와 동거를 하고 있었지만 그녀와의 관계가 무성(asexuality) 의 관계였을 수도 있다는 가능성도 추정하게 한다. 그는 자 신이 정상적인 '성인과 성인 간의 애정관계'를 형성할 수 있 을 정도로 충분히 성숙했다고 인식하지 못하고 있다. 이는 그가 어린 시절에 경험한 삶으로부터 영향을 받았을 것이며 불안정한 성 정체성에 이어 자아 정체성에도 혼란을 야기했
을 것이다. 에곤 실레가 성 정체성 확립에 어려움을 겪었던 것은 자아 정체성 혼란과 맞물려 있으며 이는 다시 자아 정 체성의 성숙에 부정적인 영향을 주었을 것이다. 에곤 실레의 아버지는 성병(sexually transmitted disease)인 매독으로 인 하여 정신과 육체가 병들었고 실레에게 이상화된 성인 남성 역할 모델로 기능하지 못하였다. 이처럼 성 정체성 확립과 자기 발달에 필요한 정신적 조직 체계가 부족했던 실레는 자신과 병든 아버지를 동일시하는 과정에서 성과 죽음에 대 해서 과도한 불안과 공포를 느꼈다. 게다가 그는 해결되지 않은 오이디푸스 갈등을 지녔기 때문에, 아버지에 대해서 두 려움과 공격성을 가졌을 뿐만 아니라 동시에 불안정한 이상 화를 보인다. 이는 성에 대한 과도한 두려움과 죄책감을 유 발할 수 있다(Kernberg 1980). 그는 성병에 감염된 아버지와 자신을 동일시하게 되면서 성인기에 외부로 성적 욕망을 실 현하는 경우 아버지와 마찬가지로 매독에 걸려 가족 모두를 파멸에 이르게 할 수 있고, 더 나아가 자신도 매독에 걸려 죽 을 것이라는 비현실적 공포를 어린 시기부터 가졌을 가능성 이 있다. 이것이 성병으로부터 안전한 자위에 집착을 하는 자화상과 손발이 잘린 자화상으로 표현된 것이다. 갈등적인 대상관계로부터 퇴행적 해리가 발생하는 상황에서 행해지는 자위는 금지된 성적인 충동 및 다른 무의식적 갈등에 대한 방어이자 타협형성이다(Kernberg 1980).

그는 자라면서 가끔 아버지의 돌아가신 혼령이 자신을 찾 아온다고 믿었다. 1913년 실레는 사촌에게 다음과 같은 편지 를 보냈다.

"왜 나의 고귀한 아버지를 진심으로 슬프게 기억하는 사 람이 없는지 모르겠다. 내가 아버지가 늘 계셨던 곳, 아버지 를 상실한 고통이 느껴지는 장소에 자주 간다는 사실을 아 는 사람이 있을까 $\cdots$ 나는 모든 생명은 영원하다고 믿는다... 내가 묘지나 죽음을 연상시키는 것들을 그려대는 이유는 무 엇일까? 그것은 내 안에 항상 죽음에 관한 생각이 들어차 있 기 때문이다."(Whitford 1981)

이처럼 에곤 실레의 죽음에 대한 공포는 남성성의 정상적 인 발달과정에 있어 부정적인 영향을 주었다. 성의 추구와 남성으로서의 성 정체성(male gender identity)은 곧 아버지 와의 동일시를 촉발한다. 성인기가 되면 자연히 해야 할 일 임에도 불구하고, 본능적 추구와 리비도의 발현은 그에게 무 의식적인 죽음의 공포와 죽음 충동을 불러일으키는 혼란을 야기하였기 때문에 그를 괴롭게 하였다. 이런 양가적 상황이 자화상에서도 반복적으로 표현된 것이다. 에곤 실레에게 있 어 남성성의 성숙한 발현은 죽음과 맞닿아 있으며 죽음 충 동과 만나 더욱 파괴적인 상황을 초래할 수 있다는 위협이 되었다. 그로 인해 그는 의도적으로 자신의 성적 발달을 억 
제하고, 자위에 집착하였으며, 자신의 남성적 신체의 발달을 왜곡하거나 부정하려는 무의식적인 소망을 자화상에서도 표현한 것이다. 동시에 그 표현은 그의 내면에서 주도적인 죽음 충동에 의해 횔씬 과격하고 균형을 깨뜨리며 비현실적 인 방식으로 나타났으며, 이것이 극대화되어 자신의 사지를 절단한 모습으로도 구현된 것이다.

에곤 실레의 성숙하지 못한 자아는 성인기의 정상적인 리 비도의 발현을 이루어 내지 못했으며 무의식을 지배하고 있 는 우세한 죽음충동의 발산을 효과적으로 통제할 능력이 없 었다. 그 결과 자기 표상을 통합하지 못한 채 세 명의 각기 다른 표정과 시선 방향을 가진 서로 다른 개체들이 한 몸에 존재하는 것으로 자신을 인식하고 있었고 이것이 '인물 구 성-삼중 자화상'이란 그림으로 드러났다. 에곤 실레는 비록 생물학적으로 성인기에 접어들었으나 심리적으로는 남성성 을 충분히 발달시키지 못했고, 남성성의 표현과 실현은 죽음 의 공포와 맞닿은 일이 되었기에 그는 이를 무의식적으로 회 피하게 되었다는 것을 이 그림들을 통해 추정할 수 있다. 비 록 그는 발리와 동거를 하였지만, 이성 관계의 만족과 타인 과의 친밀감을 통하여 형성되는 초기 성인기의 깊은 정서적 인 관계를 갖지는 못했을 것으로 보인다. 그보다는 오히려 과거 어머니와의 관계에서 얻지 못했던 보호, 돌봄, 애착에 대한 좀 더 근원적인 모자 관계(mother-child relationship) 를 재현하려는 욕구가 강했을 것이다.

\section{소 녀}

에곤 실레는 미성년이 분명한 소녀를 모델로 성적인 주제 의 그림을 여러 점 그렸다. 1910년 '검은 스타킹을 신고 앉은 소녀(Seated Female Nude with Balck Stockings)'(Figure 4) 에서 검은 스타킹을 입은 소녀가 다리를 벌리고 앉은 채 거 리낌 없이 음부를 노출하고 정면을 응시한다. 소녀의 표정을 통해 소녀가 누군가를 노골적으로 유혹하고 있기보다는 성 에 대한 순진함과 당혹스러움을 갖고 있는 것을 알 수 있다. 반면 붉은 색으로 채색된 입술, 유방, 음부가 두드러진다. 왼 손은 가슴 앞에서 얼굴을 향해 펼쳐져 있는데 유방을 가리지 않은 채 유난히 크게 그려져 있다. 즉, 성기와 손은 성숙한 여 인의 형태를 보이고 있지만 전체적인 모습은 미성숙한 소녀 의 모습이다. 1911년의 '두 소녀'에서는 붉은 계열의 옷을 입 은 두 명의 소녀가 하의를 걷어 올린 채로 포개어 누워 있다. 두 소녀가 취하고 있는 포즈는 성적인 구도이지만 실제로 성 행위를 하고 있는 것이 아니라 서로의 몸에 기댄 채 잠들어 있다. 아래에 누워 있는 소녀의 음부는 붉게 채색되어 위에 있는 소녀의 음부와 맞닿아 가리워져 있다.

이외에도 에곤 실레는 소녀를 모델로 많은 그림을 그렸는

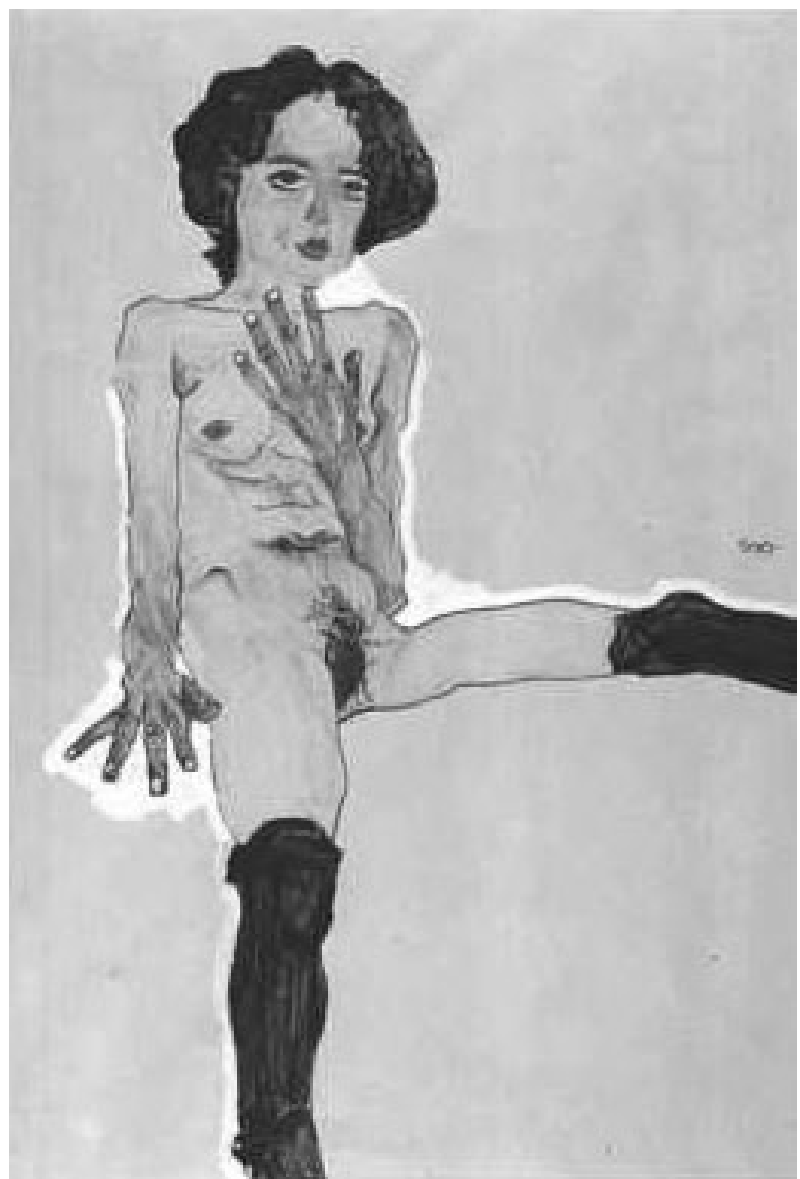

Figure 4. Seated Female Nude with Balck Stockings (1910).

데 성적인 이미지를 표현한 세미누드나 누드화가 대부분이 었다. 누드 모델에는 당시 16 세이던 여동생 게르티도 포함되 어 있었지만 그 외에는 비엔나의 하층 계급 소녀들이었다. 그는 여백과 극적인 색감의 사용을 통해 어린 소녀의 여성성 (sexuality)을 부각했다. 이런 주제는 1910년부터 1912년 사 이에 두드러졌는데, 공교롭게도 자화상을 그린 시기와 겹친 다. 선정적이고 직설적인 성의 표현에도 불구하고 실제 실레 의 성생활은 문란하지 않았으며 오히려 그는 성적으로 미숙 한 편이었다(Whitford 1981).

1912년 4월, 노이렝바흐에서 머물며 작품활동을 하던 실 레는 어린 소녀들을 모델로 한 누드 드로잉 때문에 어린 소 녀들의 옷을 벗겨 그림을 그리고 심지어 문란한 관계를 가진 다는 추문에 휩싸였고 결국 구속되었다. 21 일간의 구금 기간 동안 유괴 죄목은 무죄로 밝혀졌으나 작업실에 보관되어 있 던 작품들은 몰수되고, 3 일간의 징역형을 받아 총 24 일간 구 금되었다.

에곤 실레가 이토록 소녀와 누드라는 주제에 몰두하고, 사 법적 처벌의 대상이 될 위험에까지 빠지게 되었던 것은 그가 성적인 발달에 대해 공포를 가졌던 것과 깊은 연관이 있다. 
그의 그림은 소녀라는 미성숙한 개체를 대상으로 하는 동시 에 과도하게 성적인 부분을 강조하였는데 이는 현실적으로 적 합하지 않은 측면이 있었다. Kernberg(1980)는 애정관계를 유 지시키는 기본 요소로써 능동적이며 창조적인 사랑의 표현을 성적인 열정(passion)이라고 명명하였으며 이를 경험하기 위 하여 필요한 세 가지 요건을 제시하였다. 첫째는 Freud(1930) 가 '대양처럼 느껴지는 무경계감(the sense of boundlessness of the oceanic feeling)'이라고 명명한 공생적 융합(symbiotic fusion) 상태와 이를 지속적으로 공감할 수 있는 능력이 며, 둘째는 자기와 대상이 분화되는 단계에서 유아가 겪는 어 머니와의 흥분에 찬 재결합이나 친밀함에 대한 경험이다. 마 지막으로 세 번째 요건은 성과 관련된 열등감, 두려움, 죄책 감을 극복하는 과정에서 오이디푸스적인 갈망을 충족시키는 것이다. 에곤 실레의 경우 앞서 이 세 과정 모두에서 정상적 인 발달을 이루지 못하였고, 그 결과 정상적이며 건강한 방식 으로 성적인 열망을 성취할 수 없었을 것이다. 그는 억눌러지 지 않는 성적인 욕동과 그에 대한 공포를 동시에 느끼면서 정 신적인 갈등을 겪었고 불안에 대한 반동 형성(reaction formation)으로 성적인 묘사가 두드러지는 그림을 반복적으로 그렸다. 하지만 앞에서 언급했듯이 성은 죽음을 불러일으키 는 공포의 대상이기도 하였기에 성적인 표현을 성숙한 여인 을 통해 직접적으로 드러내지 못하고 미성숙한 소녀를 통해 간접적으로 표현했다. 또한 성적인 주제를 담고 있으나 실제 로 아직 성숙되지 못한 소녀의 모습은 실레 자신의 이중적인 모습이기도 하였다. 성의 추구는 인간이 현실 세계에서 자신 의 존재를 확인하는 가장 기본적인 방법(Lichtenstein 1970) 이나 실레는 이를 억압하고 있었기에 이성과 안정적이고 충 분히 만족스러운 관계를 형성하지 못했을 것이다. 그는 반복 적으로 소녀를 주제로 하는 그림을 그리는 창작 행위에 열중 함으로써 자신의 정신적인 갈등을 직면하고 극복하고자 했 다. 이중 욕동 이론의 기전으로 보았을 때 에곤 실레는 성적 욕동의 표현이나 정상적 발달이 억압되면서 상대적으로 죽 음과 파괴 충동에 더 집착하게 되고, 이에 대한 천착을 하며, 예술을 통해서도 이 주제에 대해서 더욱 강렬한 표현을 해낸 것으로 이해할 수 있다. 동시에 그가 성적인 추구를 통해 정 신적인 균형을 이루기에는 리비도의 발달이 미흡했기에 성숙 한 여인이 아닌 미성숙한 소녀의 형태로 성적인 그림을 반복 하였다. 한편 자아의 균형을 갖추려는 스스로의 노력은 죽음 에 대한 몰두라는 신경증적인 왜곡을 불러일으켰고 죽음충동 이 오히려 더욱 강화되는 역설적 상황이 되었다.

\section{죽음 충동의 통합}

에곤 실레는 성적 욕동의 억압과 발달의 저하, 과도한 죽
음 충동에 대한 몰입으로 자아의 혼란을 경험하고 있었다. 그럼에도 불구하고 그는 지속적으로 창작활동에 열중하면서 무의식적으로 자아의 통합을 추구하였다. 이러한 부단한 노력 의 결과물이 1915년의 '죽음과 소녀(Death and the Maiden)' (Figure 5)이다. 이 그림은 위에서 아래를 내려다보는 관점이 다. 소녀는 발리처럼 보이며 죽음으로 묘사된 남자의 얼굴도 실레 자신의 얼굴과 크게 다르지 않다. 구겨진 흰 천은 실레 와 발리와의 관계를 암시하는 듯하며 둘러싼 배경에 의해 바 닥 아래쪽의 내부로 잠식당하고 있다. 소녀의 양팔은 죽음을 감싸고 있으나 양손의 둘째 손가락을 서로 연결하여 만든 미 약한 고리는 쉽게 풀릴 수 있을 것으로 보인다. 소녀의 왼쪽 팔은 죽음의 소매에 가려 부러질 것처럼 가느다랗다. 죽음은 왼손으로 소녀의 머리를 끌어안고 자신의 가슴에 얼굴을 묻 고 있는 소녀를 안심시키려는 듯 머리를 맞대고 있는데 마치 작별의 키스를 하는 것처럼 소녀의 정수리에 입을 맞추고 있 다. 흰 천 안으로 돌아갈 수 없다는 듯이 죽음의 양 발은 흰 천 밖으로 나와 끈으로 묶여 있으며 눈은 다가올 미래를 주 시하는 것 같다.

1911년부터 에곤 실레는 클림트로부터 그림 모델로 소개 받은 당시 17 세의 발리와 동거를 시작했다. 발리는 단순히 그림 모델로서의 역할만 했던 것이 아니라 수년간 헌신적으 로 그를 보살폈다. 관계는 4년간 지속되었고, 실레가 중산층 공무원 집안인 하름스가의 딸과 결혼하면서 끝이 났다. 처음 실레가 하름스가의 두 딸과 알고 지내기 시작할 때, 발리는 실레가 자매에게 쓴 편지를 전달해 주었고 실레가 두 딸과 같 이 데이트를 할 때 동반하기도 하였다(Kuroi 2003). 그러던 중 1914년 6월 1차 세계대전이 시작되었고 에곤 실레도 입대 가 결정되었다. 입대를 3일 앞둔 1915년 6월 17일 에곤 실레

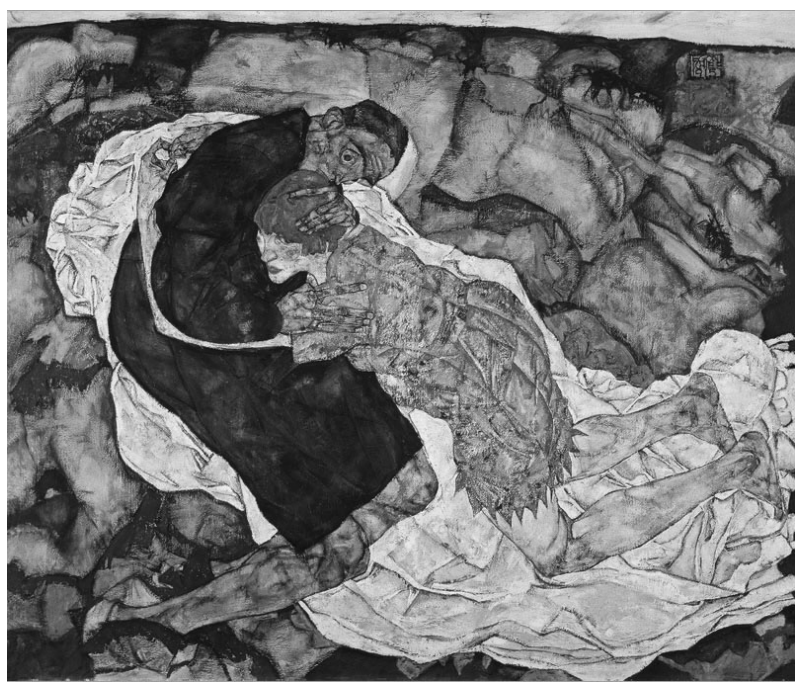

Figure 5. Death and the Maiden (1915). 
는 전격적으로 발리와 헤어지고 두 자매 중 동생인 에디트 하름스와 결혼 후에 입대를 하였다.

에곤 실레가 발리가 아닌 다른 여성과 결혼한 것은 발리 를 배신하고 죄의식이 결여된 행동을 한 것은 아니었던 것 으로 보인다. 그와 발리의 관계는 성인 남녀의 일반적 관계 와는 다른 기능을 하였다. 실레에게 있어 발리가 심리에서 차 지하는 역할이 일반적인 남녀 관계와 달랐다. 4년간의 동거 기 간 동안에 발리는 에곤 실레에게 연인이라기보다는 어머니에 가까운 역할을 하였다. 오이디푸스 갈등을 다루고 있는 1913 년 작 '성가족(The Holy Family)'에서도 어머니가 발리의 얼 굴로 표현되어 있는 점에서 이를 유추해 볼 수 있다. 이 작품 에서 그는 자신을 아기로 묘사하는 동시에 성인 남성인 아버 지로 묘사하고 있는데, 실레가 발리와의 관계 속에서 성인 남 성이지만 어린 아이와 같은 존재이기도 한 이중적인 존재였 던 것을 상징한다. 성적인 행동은 성적 욕동과 공격성에서 파 생된 충동을 리비도적 성애로 통합할 수 있게 하는데(Eisser 1975), 실레는 발리와의 관계를 통하여 안정적 애착과 대상관 계를 형성하였고 이는 실레의 정신세계에서 우세하던 죽음 충동(thanatos)이 리비도(libido)와 조화롭게 융합할 수 있는 계기가 되었다. 발리는 실레에게 있어 어머니의 대체적인 존 재였으며 발리와 관계를 경험하면서 실레는 편집-분열 자리 (paranoid-schizoid position)가 우세한 상태에서 벗어나 안 정적인 대상관계를 가질 수 있게 되었다. 더 나아가 과거의 오이디푸스 관계를 능동적으로 재구성하였고 성과 애정 관 계를 통합시킬 수 있는 성인 남성으로 성장했다. 실레가 아 버지의 죽음을 계기로 갖게 되었던 성적 욕동에 대한 강한 억압에서 자연스럽게 해방될 수 있었던 것은 발리와 안정적 으로 대상관계를 형성하면서 우울 자리(depressive position) 가 전에 비해 안정적으로 작동하여 균형 잡힌 어머니 대상 표상(maternal object representation)을 내재화할 수 있게 되었기 때문이다. 또 모든 관계를 파괴할 수 있다는 두려움 에 의해 아버지를 나쁜 대상 표상에서 분리(splitting)하던 것 에서 벗어나, 전체로 받아들이며 비로소 온전한 아버지 대상 표상(paternal object representation)을 내재화할 수 있게 되 었다. 이러한 자아 발달의 과정을 완수한 결과 성인 남성으 로 성숙하였고 타인과 친밀하고 이타적인 관계를 형성하는 결혼이라는 현실적인 과업을 성취할 수 있었다. 또한 발리와 의 결별은 일종의 분리 개별화(Separation-Individuation) (Mahler 등 1975)의 과정으로 실레가 미성숙했던 과거의 자 아와 결별하는 것으로도 볼 수 있으며, 이를 상징적으로 보 여주는 작품이 바로 ‘죽음과 소녀’다. 실레의 자아 성장은 열 정적이고 창조적인 예술적 활동을 통하여 이루어 낸 결과일 뿐만 아니라 발리와의 관계를 통해서도 이루어졌다. '죽음과
어머니'에서 어머니라는 '죽음'과 같은 존재에 압도당하던 아 기는 이제 성인 남성의 모습으로 스스로를 표현하고 그 자신 이 죽음을 대변한다. 그러나 죽음은 삶을 압도하지 않고 대 등한 위치에서 균형을 이루고 있다. 죽음과 삶이 대등한 관 계로 서로 원만한 융합을 이루고 있다는 점에서 '죽음과 소 녀'는 에곤 실레의 자아의 성장을 드러내 주는 중요한 작품 이며 이 작품을 기점으로 이후 그의 예술 세계에도 뚜렷한 변화가 보이기 시작했다.

\section{5년 이후의 예술의 변화}

1915년의 ‘죽음과 소녀'라는 작품과 에디트 하름스와의 결 혼 이후 그의 예술에는 많은 변화가 있었다. 1917년의 '어머 니와 두 아이'는 이전에 발표했던 1912년 '눈먼 어머니', 1914 년 '아이와 어머니'와 달라진 인상이다. 1912년 작 '눈먼 어머 니'에서는 아이의 눈이 없고 어머니는 아이를 바라보지 않는 다. 이에 반해서 1917년 작 '어머니와 두 아이'는 더 밝은 색채 로 그려졌으며, 오른 팔에 안긴 아이는 생기가 있고, 어머니 를 바라보려는 시도를 하고 있다. 어머니의 시선은 아이를 향 한 듯하지만 무표정하고 생기가 없는 면은 지속된다. 1917년 의 '포옹'은 따뜻하고 평온한 노란 빛의 배경으로 육감적이며 성숙한 몸을 지닌 전라의 두 남녀가 흰 천 위에 누워 있다. 여 자는 관객 쪽으로 몸을 돌리고 있으나 남자를 껴안고 기대 어 고개를 숙이고 있어 얼굴은 보이지 않는다. 서로를 양팔 로 감싸 안으며 끌어당기는 힘에 의해 두 남녀의 상반신은 온전히 밀착되어 있는데 전체적인 분위기가 죽음이나 파괴 를 연상시키기보다는 안정적인 관계와 평온하고 만족스러 운 애정관계를 묘사하고 있다. 1918년의 '가족(The Family)' (Figure 6)은 안정적인 구도 안에서 맨 뒤에 에곤 실레로 보 이는 남자, 중간에 에디트로 보이는 여성, 맨 앞에 아기가 앉 아 있다. 남자의 오른손이 왼쪽 가슴에 닿아 있는 것은 마치 어떤 다짐이나 맹세를 하는 것 같고 넓은 어깨와 긴 팔은 자 신의 아내와 자식을 보호하듯 펼쳐져 있다. 과거의 그림들과 달리 어머니와 아이 모두 온전한 신체를 갖고 있고 좋은 영 양상태를 보이며 전체적으로 평화로운 가족의 모습이 표현 되었다.

전쟁 중이었지만 결혼 이후 에곤 실레의 삶은 안정되었다. 군복무 중에도 그림을 계속 그릴 수 있었고, 1916년에는 네 번의 전시회를 갖기도 했다. 1918년, 클림트가 뇌졸중으로 사 망하자 28세의 실레는 클림트를 계승하여 빈에서 가장 선두 에 선 화가로 인정받았다. 분리파의 49회 정기전시회에서 실 레는 중추적인 역할을 하였고 그의 작품은 이례적으로 높은 가격에 팔렸다.

에곤 실레는 후기 작품에서도 생애 초기 어머니와의 대상 


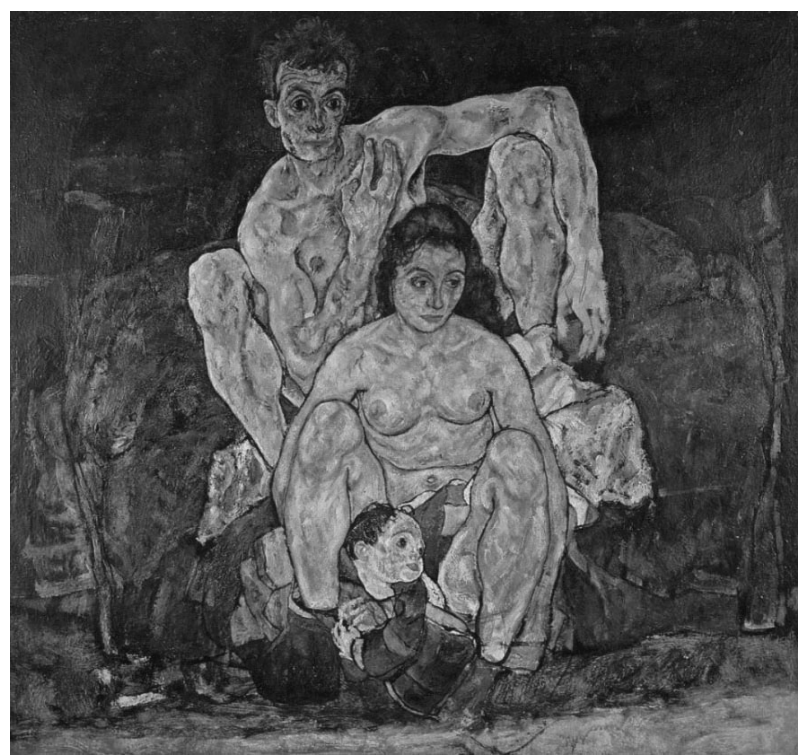

Figure 6. The Family (1918).

관계 형성의 실패에서 오는 절망을 주제로 그림을 그리지만 더 이상 자신을 어머니에게 예속되어 억눌리는 상태로 묘사 하지 않았다. 또한 초기 작품에서처럼 어머니를 향한 절망과 공포 같은 부정적인 감정을 혼돈과 공황상태로 표현하지 않 았다. '어머니와 두 아이'에서 남자 아이와 여자 아이는 에곤 과 게르티를 상징하는 듯하다. 초기 작품에서처럼 어머니를 박해자로 묘사하고 자신을 피해자로 묘사한 1대 1 의 구도로 작품을 설정하지 않았다. 그는 어린 시절의 외상적 사건을 떠 올릴 때 자신과 같은 아픔을 겪은 형제를 함께 떠올릴 수 있 게 되었고 과거의 어머니를 보다 더 객관적이고 사실적인 시 각으로 평가하게 되었다. 어머니를 죽은 존재로 보기보다 불 쌍한 존재로 객관화하고 공감하려는 연민의 마음을 가질 수 있게 된 것이다. 이는 그의 자아가 성숙을 통해 어머니를 자 신을 억압하고 죽이려고 하는 위협적인 존재로 인식하는 편 집-분열 자리(paranoid-schizoid position)가 주도적인 상황 에서 벗어난 것을 의미한다. 자아의 성숙 이후에도 여전히 어 머니와 안정적으로 대상 관계를 형성하지 못한 것은 실레에 게 비극적인 사건이었지만 어머니에게 연민을 갖고, 회복의 가능성을 갖고자 노력하는 우울 자리(depressive position)가 보다 주도적인 위치에서 작동하게 되었음을 그림의 변화로 알 수 있다. 후기 작품에서 묘사된 어머니의 모습은 실레가 대상을 좋기도 하고 나쁘기도 한 전체로서 경험하는 능력을 갖게 되었다는 것을 보여준다. 이처럼 깊이 있는 인간 관계를 성립하기 위해서는 양가 감정의 수용을 전제로 하며 그 근저 에는 타인을 완전히 경험하는 능력이 필요하다(Kernberg 1976).

에곤 실레가 표현한 여성의 모습은 성에 대한 그의 인식의
변화를 나타냈다. 앞서 언급했듯이 에곤 실레에게 있어 성과 여성은 열망의 대상인 동시에 두려움과 공포의 존재였다. 초 기 작품들에서의 형태가 비틀린 채로 앙상하게 빼가 드러나 고 벗겨진 무성(asexuality)의 소녀는 그의 취약하고 억압된 성적 욕동이 투사된 결과물이었다. 후기 작품들에서 나타난 여성은 관능적이며 건강하게 살이 오른 모습이고 부드러운 표정을 짓고 있다. 여성은 소녀가 아닌 성숙한 여성으로 등 장하며 그는 더 이상 소녀를 그리는 데 몰두하지 않게 되었 다. 성적인 주제를 표현하는 데 있어 죽음이 동반되지 않았으 며 성은 자아의 조절하에 건강하게 발산되었다. '포옹'에서도 알 수 있듯이, 후기 작품들은 초기 작품들과 달리 직접적인 성기의 묘사를 절제하고 있고 성은 은밀하고 간접적으로 드 러나며 현실적이며 안정적인 관계 안에서 표현된다. 이제 실 레에게 성은 더 이상 공포와 죽음, 회피의 대상이 아니며 풍 요와 안락의 대상이 되었다. '포옹'은 이성애적인 성(heterosexuality)을 극명하게 드러내는 작품으로 작품 속의 남성과 여성은 자신의 성을 뚜렷하게 드러내는 성숙한 모습으로 묘 사된다. 성기적 동일시(genital identification)는 정상적인 애 정 관계에서 필수적인 요인이며, 이는 개인이 자신의 성 역할 과 완전하게 동일시할 수 있으며 애정 대상의 보완적인 성 역 할에 대해 공감할 수 있는 능력을 포함한다(Kernberg 1976). '포옹'에 묘사된 두 남녀는 명확한 성 정체성을 지니며 서로에 게 안정적으로 애착 관계를 형성하고 있고 대등하게 공존하 는 성숙한 사랑을 표현한다. 성숙한 초자아는 온전한 성 경험 을 가로막는 전성기적 공격성(pre-genital aggression)과 동성 애적 요소를 포함하는 유아적인 금지부터 자아를 자유롭게 한다(Kernberg 1980). 에곤 실레는 성숙한 초자아의 기능을 통해 성기적 성애(genital sexuality)를 애정 관계 안으로 통합 하여 완전한 성적 기쁨을 누릴 수 있는 능력을 갖게 되었다.

남성은 사랑하는 여성과 성적인 관계를 맺을 수 있을 뿐 만 아니라 이러한 상황에서 부성적인 기능과 관대함의 기능 을 수행함으로써 오이디푸스 아버지와의 동일시라는 마지 막 경계를 넘어야한다(Braunschweig와 Fain 1971). 에곤 실 레는 '가족'을 통해 헌신적인 아버지 역할을 하는 자신의 모 습을 작품 속에 담아냈고 한 차원 더 높은 수준의 자아 성장 에 대한 소망을 보여줬다.

\section{결 론}

Freud(1930)는 예술을 신경증의 산물로 생각하였으며 예 술 활동은 근원적인 충동(drive)의 승화이고 예술가는 본능 적인 충동의 환상을 미학적으로 승화시키는 능력을 갖추었 다고 하였다. 또 이러한 예술적 승화를 통한 본능 에너지의 
배설은 정신적인 긴장의 이완을 이러한 예술적 승화를 통한 본능 에너지의 배출은 정신적 긴장의 이완을 가져온다고 하 였다. 자아 정체성의 혼란과 죽음 충동의 우세는 에곤 실레 에게 삶의 다양한 국면에서 문제를 유발했다. 그는 자신의 정신 병리와 관련된 손상과 상실에 대한 주제를 작품 속에서 반복적으로 다루면서 예술로 극복하고자 하였다. 에곤 실레 에게 있어 예술의 추구는 자가 치유와 성숙의 과정이었다. 에곤 실레는 어린 시절에 매독 감염에 의한 아버지의 죽음, 잇따른 자녀의 죽음을 겪은 우울한 어머니, 집안의 몰락 등 을 경험하면서 어머니와 안정적으로 애착을 이루지 못했고, 성적 욕동을 안정적으로 발달시키지 못했으며, 죽음에 대한 두려움을 극복하기 위한 역공포적 대응을 반복하였다. 에곤 실레에게 있어 남성성의 발달은 아버지와의 동일시를 의미 하였고 죽음과 파멸이 가까워 올 것이라는 무의식적 두려움 을 불러일으켜 성과 남성성에 대한 억압을 가져왔다. 성적 욕망의 억압은 죽음 욕망에 대한 과도한 집착과 몰두로 이어 졌고, 이는 그의 작품에서 반복적으로 드러났다. 그러나 에 곤 실레는 이러한 상태에 머무르지 않고 창작성을 발휘하면 서 정신세계에서 상처의 고통을 분리(psychic splitting)해 낸 후 창작 과정을 거쳐 완숙(mastery)하였고 스스로 재통합 (reintegration)의 과정을 거쳤다(Rose 1987). 그는 손상된 자 아를 극복하고 스스로 자아 정체성을 형성하였으며 성적인 영역과 대상 관계 영역에서의 성숙을 이루어 낼 수 있었다. 그리고 이는 그의 결혼과 가정의 형성, 그리고 작품의 변화 를 통하여 입증되었다.

여러 가지 논란이 있지만 죽음 충동은 강력한 인간의 근 원적 충동으로 손상된 자아를 지니는 개인에게 있어서는 특 히 극복해 내기 어려운 난관일 수 있다는 것을 에곤 실레를 통해 입증할 수 있었다. 향후 정신분석적 치료를 하는 데 있 어서 죽음충동의 존재와 작용, 정신기제 안에서의 위치에 대 한 면밀한 평가가 관심을 두고 진행되어야 한다는 함의를 갖 는다. 한편 죽음 충동이 우세한 경우라 해도 자아는 본능적으 로 스스로를 치유하고 진화하려는 노력을 하게 되며 창작을 하거나 어머니의 대체 대상을 만나는 것과 같은 다양한 노력 을 통하여 죽음 충동에 굴복하지 않고 죽음 충동을 잘 통제하 여 성숙한 인격으로 발달해 나갈 수 있다. 저자들은 이 논문 을 통해서, 내재화된 대상 관계의 연속적인 발달 단계들이 자 아와 초자아의 통합 정도, 우세한 방어 기제와 성격 특성, 그 리고 정신 병리의 정도와 유형의 특징을 결정짓는다는 기존 의 정신분석학적 이론을 확인할 수 있었다. 동시에 예술을 통 해 충동의 불균형이 승화되고, 성숙한 자아가 내재화된 대상 관계적 구성물의 중심적 요소로서 기능하여 삶 충동(eros)과
죽음 충동(thanatos)의 두 요소들을 조화롭게 통합시킬 수 있 음을 알았다. 이는 에곤 실레의 삶과 작품의 변화를 통해 뚜 렷하게 관찰할 수 있었다. 이와 같이 예술은 자아와 삶에 대 한 심원한 통찰의 도구이며 손상된 자아와 대상 관계를 회 복하고자 하는 치열한 노력일 수 있음을 알 수 있다.

\section{Conflicts of Interest}

The authors have no financial conflicts of interest.

\section{REFERENCES}

Bellak L, Meyers B. Ego function assessment and analysability. Int Rev Psychoanal 1975;2:413-427.

Blum HP. The prototype of preoedipal reconstruction. J Am Psychoanal Assoc 1977; 25:757-785.

Braunschweig D, Fain M. Eros at Anteros. Paris: Petit Bibliotheque Payot; 1971 .

Eisser KR. The fall of man. Psychoanalytic study of the child. New Haven: Yale University Press;1975. p.589-646.

Erikson EH. The problem of ego identity. J Am Psychoanal Assoc 1956; 4:56-121.

Freud S. An outline of psychoanalysis. SE 23. London: Hogarth Press; 1940a.

Freud S. Beyond the pleasure principle. SE 18. London: Hogarth Press; 1920.

Freud S. Civilization and Its Discontents. SE 21. London: Hogarth Press;1930. p.57-145.

Freud S. Splitting of the Ego in the defensive process. SE 23. London: Hogarth Press; 1940 b.

Freud S. The Ego and the Id. SE 19. London: Hogarth Press;1923.

Kernberg O. Borderline conditions and pathological narcissism. New York: Jason Aronson; 1975.

Kernberg O. Internal world and external reality. New York: Jason Aronson; 1980 .

Kernberg O. Object relations theory and clinical psychoanalysis. New York: Jason Aronson;1976.

Klein M. On the theory of anxiety and guilt. In: Envy and gratitude and other works, 1946-1963. New York: Free Press; 1975.

Kuroi S. Egon shiele naked soul 1890-1918. Seoul: Da Vinci Pulblishing;2003.

Laplanche J, Pontalis JB. Vocabulaire. de la psychoanalyse. Paris: Presses Universitaires de France;1967. p.431-438.

Lichtenstein H. Changing implications of the concept of psychosexual development. An inquiry concerning the validity of classical psychoanalytic assumptions concerning sexuality. J Am Psychoanal Assoc 1970;18:300-318

Mahler MS, Pine F, Bergman A. The psychological birth of the human infant: symbiosis and individuation. New York: Basic Books;1975.

Niederland WG. Psychoanalytic approaches to artistic creativity. Psychoanal Q 1976;45:185-212.

Noy P. Form creation in rat: an ego-psychological approach to creativity. Psychoanal Q 1979;48:229-256.

Noy P. Insight and creativity. J Am Psychoanal Assoc 1978;26:717-748.

Rose GJ. Trauma and mastery in life and art. New Haven, CT: Yale University Press;1987. p.1-20.

Segal H. Manic reparation. In: The work of Hanna Segal: a Kleinian approach to clinical practice. New York: Jason Aronson;1981. p.147-158.

Whitford F. Egon Schiele. New York: Oxford University Press;1981.

Winnicott DW. Playing and reality. New York: Basic Books;1971. 